Research Report No. 17/2013

\title{
The Political Origins of English Private Law
}

Dan Priel

Osgoode Hall Law School of York University, dpriel@osgoode.yorku.ca

Follow this and additional works at: http:/ / digitalcommons.osgoode.yorku.ca/clpe

\section{Recommended Citation}

Priel, Dan, "The Political Origins of English Private Law" (2013). Comparative Research in Law \& Political Economy. Research Paper No. $17 / 2013$.

http://digitalcommons.osgoode.yorku.ca/clpe/266 


\section{OSGOODE}

OSGOODE HALL LAW SCHOOL

YOR K UN I VERSITY

\section{OSGOODE HALL LAW SCHOOL}

Comparative Research in Law \& Political Economy

RESEARCH PAPER SERIES

Research Paper No. 17/2013

\section{The Political Origins of English Private Law}

Dan Priel

\section{Editors:}

Peer Zumbansen (Osgoode Hall Law School, Toronto, Director Comparative Research in Law and Political Economy)

John W. Cioffi (University of California at Riverside)

Leeanne Footman (Osgoode Hall Law School, Toronto, Production Editor)

Comparative Research in Law \& Political Economy 


\section{The Political Origins of English Private Law Dan Priel $^{*}$ \\ (Forthcoming (2013) 40 Journal of Law and Society.)}

These days it is common to see the divide between private and public law presented as a fundamental distinction of English law. This is an interesting development because it reflects a complete turnaround from what was considered until recently one of English law's defining characteristics. Furthermore, to the extent that people have drawn the distinction between private and public law in the past, it was typically in an attempt to point to the newly emerging public law and distinguish it from the rest of the (private) law. Today, by contrast, it is more common to see the argument pushed in the opposite direction, in an attempt to separate private law from the rest of the (public) law. This, I will argue, is not simply a different way of telling the same story.

Historically, English law did not recognize a division between private and public law, ${ }^{1}$ and by the time we got to Dicey, this was not merely a recognized feature, but a matter of national identity: "when we speak of "the rule of law" as a characteristic of our country', he wrote, '[w]e mean ... that here every man, whatever be his rank or condition, is subject to the ordinary law of the realm and amenable to the jurisdiction of the ordinary tribunals'. ${ }^{2}$ Dicey further explained that England did not have anything 'of the nature and principles of what is called in France droit administratif. ${ }^{3}$ These claims have come under attack over the years, but they have had considerable staying power. For instance, in $196_{5} \mathrm{John}$ Mitchell wrote an article that described and criticized (as its title had it) 'the causes and effects of the absence of a system of public law in the United Kingdom'. ${ }^{4}$ As late as 1983 Lord Wilberforce could express some reticence about 'import[ations] into the law of England from countries which, unlike our own, have separate systems concerning public law and private law. ${ }^{5}$

\footnotetext{
* Assistant Professor, Osgoode Hall Law School, York University. I thank participants at a faculty workshop at Osgoode Hall Law School as well as David Howarth and the anonymous referees for the Journal of Law and Society for their comments.

1 See J.W.F. Allison, A Continental Distinction in the Common Law: A Historical and Comparative Perspective on English Common Law (1996) 7-8. Allison further contends that the 'categorical' approach that the division between public and private law is only part of, is alien to the common law. Ibid, 122-24. Here too, we see an interesting development as the categorical or taxonomical approach has been at the heart of the emerging private law. See note 8 below.

${ }^{2}$ A.V. Dicey, Lectures Introductory to the Study of the Constitution (1885) 177-78.

${ }^{3} I d$., 179 .

${ }^{4}$ J.D.B. Mitchell, 'The Causes and Effects of the Absence of a System of Public Law in the United Kingdom' [1965] Public Law 95.

${ }^{5}$ Davy v. Spelthorne Borough Council [1984] A.C. 262, 276 (Lord Wilberforce, dissenting).
} 
Despite this history, a group of scholars, whom I will henceforth collectively designate 'the Private Lawyers', has sought to tell us that the distinction between public and private law is one of English law's foundational divides. For them, insisting on this distinction marked the maturing of the English legal system from its messy past into its more rationally ordered present. Peter Birks, the intellectual leader of the Private Lawyers, believed that '[n]o department of human knowledge ever advanced without attention to taxonomy', ${ }^{6}$ and dedicated boundless energy to identifying the 'correct' one. The most fundamental, axiomatic, distinction in his classificatory scheme was between public and private law. As he put it, '[t] he whole law is either public law or private law. There is no need to pause on this, nor to investigate boundary disputes'. ${ }^{7}$ No excluded middle, no possible overlaps.

Against this 'internal' explanation of the rise of English private law, offered by the Private Lawyers themselves and presented as reflecting the true nature of law, I will offer a competing account. My account explains the emergence of private law in terms of political changes in Britain; more specifically, my argument will aim to show that, surprisingly, the emergence of private law as a separate domain of English law has been grounded in the same political convictions that lay behind the view that a century before led Dicey to reject the divide. ${ }^{8}$

My argument contains six steps. I start by presenting Dicey's conception of English law and show how it is related to his political and economic liberalism. I argue that Dicey's view of law was aligned with a conception of the state concerned primarily with the protection of rights and not to the promotion of welfare. I then argue that the emergence of the welfare state in the twentieth century forced not so much abandonment of this conception of law but its reworking in order to accommodate the development and increasing centrality of public law. A central element of this reinterpretation of the Diceyean model involved the sharpening of the division of labour between law-making (to be done by Parliament) and lawinterpretation and application (the job of courts). In the third step I argue that this development put pressure on the common law and in particular on 'private law', for

${ }^{6}$ P. Birks, 'Rights, Wrongs, and Remedies' (2000) 20 Oxford J. of Legal Studies 1, 37.

${ }^{7}$ P. Birks, 'Introduction', in English Private Law, i (2000) xxxv, xxxvi.

8 There has been some critical work on the questionable assumptions of Private Lawyers' taxonomical work. See J. Dietrich, 'What Is "Lawyering"? The Challenge of Taxonomy' (2006) 65 Cambridge Law J. 549; C. Webb, 'Treating Like Cases Alike: Principle and Classification in Private Law', in A. Robertson \& T.H. Wu (eds.), The Goals of Private Law (2009) 215 ; S. Waddams, 'Classification of Private Law in Relation to Historical Evidence: Description, Prescription, and Conceptual Analysis' (2004) 6 Current Legal Issues 265. While they have shown how one needs a perspective from which to conduct a taxonomical exercise, what they have not shown is how the felt need for taxonomy, and the most basic taxonomical division-between public and private law-are themselves products of the political structure in which English law operates. American law, for example, where pressures were very different accords much less place for the public law/private law divide. There, well-known critiques of the divide have been made as early as the 1920 . See M.R. Cohen, 'Property and Sovereignty' (1927) 13 Cornell Law Rev. 8; R.L. Hale, 'Coercion and Distribution in a Supposedly Non-Coercive State’ (1923) $3^{8}$ Politcal Science Q. 470. 
these were areas where law-making traditionally resided with the courts. As a result what may have seemed unproblematic before now threatened the legitimacy of these areas of law. I argue that the emergence of private law was a response to this challenge. I describe the development of both theoretical ideas and practical solutions that were meant to address this challenge. In the fourth step I argue that these solutions were remarkably similar to Dicey's conception of law. In other words, I argue that the effort to identify English private law as distinct from public law were made by adopting on a smaller scale a Diceyean conception of law previously meant to describe the whole of English law. This implies, in the fifth and possibly most contestable step in my argument, that the means by which private law was supposed to overcome the legitimacy challenge were unsuccessful. Despite its proponents' aspirations for developing a non-political law, the work of many Private Lawyers reveals the same political ideology found in Dicey's work. In the final step, I consider the possible implications to be drawn from this for the future development of private law.

\section{II}

The British welfare state was a long time in the making; it did not appear fully formed after the Beveridge Report. And yet, for all the talk of the $18_{34}$ Poor Laws or the Victorian origins of the British welfare state, in 1885 , when the first edition of Dicey's Lectures was published, the British state was still small by contemporary standards. At the time, many among the intellectual elites still considered state intervention suspect. ${ }^{9}$ Dicey was an enthusiastic supporter of this small state and the laissez faire ideology that joined it. He counted among its virtues that it 'stimulated energy of action[,] ... left room for freedom of thought and individuality[,] ... has fostered trust in self-help[, and] ... has kept alive emphatically the virtues of the English people'.$^{10}$ He contrasted all this with what he took to be the mistaken belief that 'law can benefit the people as much as does the maintenance of personal freedom'. ${ }^{11}$ Law, in short, could and should be used to protect individual rights, not to promote general welfare. ${ }^{12}$

${ }^{9}$ See P. Harling, The Modern British State: An Historical Introduction (2001) ch. 3; J. Harris, Private Lives, Public Spirit: Britain I870-1914 (1993) 197-200. Interestingly, both Harling (at p. 73) and Harris (at p. 184) stress a model of (respectively) a 'disinterested state' or 'a neutral, passive, almost apolitical state' as the hallmark of the Victorian state, a model reproduced in Private Lawyers' conception of private law. See text to note 89 below.

${ }^{10}$ A.V. Dicey, Lectures on the Relation between Law and Public Opinion in England During the Nineteenth Century (1914, 2nd ed.) lxxi.

${ }^{11} I d$., lxxiii.

${ }^{12}$ On the extent to which Dicey's reading of the English constitution was a product of his political commitments see B.J. Hibbits, 'The Politics of Principle: Albert Venn Dicey and the Rule of Law' (1994) 23 Anglo-American Law Rev. 1; see also W.I. Jennings, 'In Praise of Dicey: 1885-1935' (1935) 13 Public Administration 123, 128. 
In his Law and Public Opinion Dicey identified the rise of collectivism around the $187 \mathrm{Os},{ }^{13}$ a development Dicey thought was inconsistent with the individualism he took to be a national English trait. I mention this not because Dicey's broad historical sweep has been universally accepted, but because it reflects his perception of the proper role for law to play. With the rise of collectivism Dicey saw danger to liberty, and he was wary of courts' feeble stand to protect it. He acknowledged that the cause of freedom was secured by favourable public opinion, but he sought stronger protection through the law, as " $[p]$ ublic opinion is ... no sound basis on which to rest as a security against the practical operation of laws which in theory are not favourable to freedom.' ${ }^{14}$

One way of understanding Dicey's work on the constitution, then, is as an attempt to inculcate a vision of law that helps protect these freedoms. Dicey saw a clear tie between the (English) rule of law, political freedom and economic liberalism. $^{15}$ For Dicey this concept denoted the fact that in English law the principles of private law have with us been by the action of the Courts and Parliament so extended as to determine the position of the Crown and of its servants; thus the constitution is the result of the ordinary law of the land' ${ }^{16}$ What this meant was that the solution to what Dicey called the growth of 'collectivism' was not to be resolved by extending and reinforcing judicial supervision (what we would now call 'administrative law') over otherwise unrestrained (discretionary) government action, but by means of limiting government powers to those given to individuals. These common law limits on the development of the law were premised on the idea that individual freedom is paramount, and that the clarity and fixity provided by judgemade law "promotes justice more than good laws [i.e., statutes] which are liable to change or modification'. ${ }^{17}$

Perhaps more surprisingly given how much the notion of Parliamentary sovereignty is now associated with Dicey, he was wary of it. A principle that 'as an abstract doctrine' might 'command the acquiescent admiration of the commentator'

${ }^{13}$ Dicey, n. 10, pp. $64-65$, lectures VII-VIII.

${ }^{14}$ A.V. Dicey, 'The Legal Boundaries of Liberty' (1868) 13 Fortnightly Review (n.s.) 1, 13; Dicey expressed the same view many years later. See A.V. Dicey, Introduction to the Study of the Law of the Constitution (1915, 8th ed.) xxxvii.

${ }^{15}$ Dicey, n. 10, pp. ${ }_{175^{-7}} 6$, where Dicey ties the rule of law with individual freedom, and 'Benthamism' (which elsewhere, id., 44, 145, he equated with laissez faire ideology).

${ }^{16}$ A.V. Dicey, Lectures Introductory to the Study of the Law of the Constitution (1885) 216.

${ }^{17}$ Dicey, n. 10, p. 366. In the choice between these two models of checking government power-either by setting limits on what government can do on the basis of principles applicable to everyone or by developing special principles for limiting executive actionDicey may have been more attracted to the former, because of its better fit to his model of the rule of law. But this choice, made on the basis of a desire to limit government, may have led, paradoxically, to the opposite result. Once Parliament granted powers to executive agencies, there was virtually nothing (outside of feeble Parliamentary control) to check them. Thus, Dicey's influential views on the inexistence of administrative law within English law may have led to a retardation of judicial developments, thereby making it easier for executive power to grow without control. 
was in reality 'an instrument well adapted for the establishment of democratic despotism'. ${ }^{18}$ It is for this reason that he looked favourably to the United States and its written, entrenched, constitution. There, he saw a regime in which the rule of law meant judicial supremacy. As he saw it, the US Constitution provided a safeguard 'against the promotion of that constant legislative activity which is a characteristic feature of modern English life', ${ }^{19}$ perhaps especially so in a period when a majority on the United States Supreme Court was similarly sympathetic towards economic liberalism. ${ }^{20}$

A conservative, Dicey preferred the 'slow and sure kind of progress which alone has the remotest chance of producing fundamental and beneficial social changes', ${ }^{21}$ and believed that it was judge-made law that was more likely to achieve this goal. But it was not just conservatism. Dicey believed that the common law was committed to equality in a way that legislation was not: its substantive rules applied to everyoneprivate individual or public body-in the same way. ${ }^{22}$ This allowed it to be principled in a way that legislation could not. 'Even ordinary judicial legislation is logical, the best judicial legislation is scientific' ${ }^{23}$ By contrast, 'Parliament in most instances pays little regard to any general principle'; rather, it 'attempts to meet the easiest and most off-hand manner some particular grievance or want', and for this reason 'can at best be called only tentative'. ${ }^{24}$ That is why he thought common law principles were more likely to promote the common good; by contrast, 'in matters of legislation men are guided in the main by their real or apparent interest' and not 'in accordance with their opinion as to what is a good law'. ${ }^{25}$

\section{III}

Dicey's view was an influential articulation of a prevailing view among legal elites about the relationship between law and state. But the British state was changing. The liberal welfare reforms starting in 1906 had a noticeable effect, and were difficult to reconcile with the picture of law as (merely) the protector or rights. These changes called for a reaction and possibly a change. In an article published in 1915 Dicey recognized that 'the nation as represented in Parliament has undertaken to perform

${ }^{18} I d$., 305-o6. Dicey invokes here Bentham's 'sinister interest', but turns it on its head. For Bentham the sinister interest was reason to limit the common law courts and to expand democracy, Dicey saw in it the reason to turn to the courts, which he thought much less corrupt (and corruptible) than legislatures. Cf. A.V. Dicey, 'Judicial Policy' (1874) 29 Macmillan's Mag 473, 473-74.

19 Dicey, n. 10, p. 9; see also H.A. Tulloch, 'Changing British Attitudes towards the United States in the 188os' (1977) 20 Historical J. 825, 837-38; Hibbits, n. 12, pp. 28-29.

${ }^{20}$ See Herbert Hovenkamp, Enterprise and American Law, I837-1937 (1991) 181-82.

${ }^{21}$ Dicey, n. 10, pp. Ixxxvii-lxxxviii.

${ }^{22}$ Dicey, n. 16, pp. $177-78$.

${ }^{23}$ Dicey, n. 10, p. 371 note 1 ; see also Hibbits, n. 12, p. 12.

${ }^{24}$ Dicey, n. 10, pp. 370-71 note 1.

${ }^{25} I d ., 12$. 
a large number of duties with which before the Reform Act of 1832 no English government had any concern whatever. ${ }^{26}$ Though unhappy about these developments, he tried to console himself that the developing law to limit government action fell short of 'true droit administratif because government action was still tried in the 'ordinary law courts'. ${ }^{27}$ Though he no longer could say that the substantive rules applicable to the government were the same common law rules which governed individuals, he could still make the weaker claim that English law did not have specialized tribunals dealing with claims against the state.$^{28}$ Even at the time this effort seemed strained and with the growth of state institutions and the greater discretionary powers given to bureaucrats, Dicey's idea of the rule of law proved difficult to sustain. One had to either give up on the idea that the same law must be applied to all, or develop new doctrines of administrative law to guarantee that government officials were constrained by law. The former would have implied putting much government action effectively above the law, the latter required abandoning the legal equality between private individuals and public bodies that Dicey considered a hallmark of the (English) rule of law. Either way, a central tenet of his original conception of the rule of law had to be abandoned.

Legal solutions to new problems are rarely completely novel and this one was no exception. It was built out of the building blocks of another central ingredient of Dicey's account, Parliamentary sovereignty. The origins of Parliamentary sovereignty are, of course, much older than late Victorian Britain, ${ }^{29}$ but the idea grew in significance with the advent of the welfare state, for it was then that the potential clash between law (and the rule of law) and government became evident. The reconciliation of the concern about the loss of freedoms that came with expanding state powers and the doctrine of Parliamentary sovereignty called for a division of labour between political and legal critique. More specifically, the solution adopted was a kind of compromise between what I will call, departing from prevailing usage, 'public law' and 'administrative law'. By the former term I mean the law directed at the government and concerned with maintaining the security and welfare of the general population; by the latter, I mean the law concerned with setting limits on the way these laws are actually implemented. Broadly speaking the solution involved a division of labour between public law—the substantive law of public bodies—which

${ }^{26}$ A.V. Dicey, 'The Development of Administrative Law in England' (1915) 31 Law $Q$. Rev. 148, 149. The last edition of Dicey's Law of the Constitution to be published in his lifetime came out in the same year. It contains a long introduction which reads like a lament for lost verities,

${ }^{27} I d ., 152$.

${ }^{28}$ Others were even less complacent than him, expressing concern about the creation of new tribunals outside the ordinary court system. See W.J.L. Ambrose, 'The New Judiciary' (1910) 26 Law Q. Rev. 203, which saw with alarm the fact that administrative bodies have been given what were essentially judicial powers. This view was then trumpeted with much greater fanfare in Lord Hewart, The New Despotism (1929).

${ }^{29}$ On the decline of the idea of fundamental law that can trump Parliamentary legislation see Bernard Baylin, The Ideological Origins of the American Revolution (1992, rev. ed.) 198-202; J.W. Gough, Fundamental Law in English Constitutional History (1961, rev. ed.) ch. 12. 
was considered largely off-limits for the courts, and administrative law-the law of administrative process. Courts had relatively little to do with the content of public law, but they took upon themselves the task of developing and enforcing a body of legal principles dealing with administering it.

However politically unhappy some economic liberals may have been about the growth of the state, Parliamentary sovereignty left them bereft of legal means for attacking these developments. The lawyers who waged the rear-guard battle against the administrative state could not object to the fact that Parliament now adopted legislation they did not approve of. Instead, they concentrated their efforts on controlling the unconstrained discretionary power to bureaucrats. Lord Hewart, for instance, may have been unhappy about the content of much of the new welfare legislation, but in The New Despotism he complained about something else, namely the allocation of decision-making power without limit or control, or as he called it, 'administrative lawlessness'. ${ }^{30}$ Contrary to Dicey, Hewart contrasted English law unfavourably with French administrative law. When the French spoke of droit administrative, he said, they had real law in mind: 'The essential idea which underlies and gives meaning to droit administratif is not that State officials ... are above the law.... It is rather that the position and liabilities of State officials, and the rights and liabilities of private individuals in their dealings with officials as such, form a separate and distinct chapter of law'. ${ }^{31}$ The French system was therefore one of "true "administrative law," administered by a tribunal which applies judicial methods of procedure'. ${ }^{32}$ This is what English lawyers had to develop.

Put differently, the doctrine of Parliamentary sovereignty is the reason why one cannot speak of an English Lochner ${ }^{33}$ era, i.e. an era of court-imposed legal limits on the permissible growth of state powers and institutions. But unlike the abnegating position Parliamentary sovereignty implied in relation to the substantive powers given by legislation to the executive branch, the doctrine of Parliamentary sovereignty proved a fruitful basis for developing the doctrines of administrative law. Doing so required reconciling the idea-very much at the core of Parliamentary sovereignty-that courts do not make rules, only interpret them. This was done in two ways. First, these new rules of administrative law that the courts did develop were not conceived of as an incursion into the domain the substantive public law; they were merely rules, derived from traditional common law doctrines, on how public law is to be fairly maintained. Second, the justification for these new rules was itself

${ }^{30}$ Hewart, n. 28, p. 43, passim.

${ }^{31} I d$., 37, also $i d ., 39-40,45$. Hewart is sometimes quoted saying 'Between the rule of law and what is called "administrative law" (happily there is no English name for it there is the sharpest possible contrast)'. Id., 35. Taken out of context this sentence gives a rather misleading impression of the book's message.

${ }^{32}$ Id., 39. Writing around the same time others expressed similar ideas. See J.A.R.

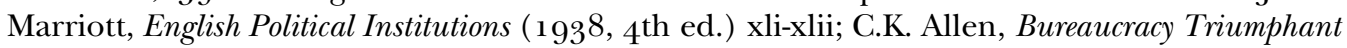
(1931).

${ }^{33}$ Lochner v. New York, 198 U.S. 45 (1905). Roberts v. Hopwood [1925] A.C. 578, conveyed a similar sentiment, but it involved local government policy, not Parliamentary legislation. 
grounded in the idea of Parliamentary sovereignty. Courts could inspect the way legislative power was exercised in order to make sure that the executive did not exceed powers granted to it by the legislature. As such, administrative law could have been (and was) explained as an affirmation of Parliamentary sovereignty. ${ }^{34}$ In Taylor v. Brighton Borough Council Lord Greene MR is reported to have said during oral argument: 'The common law does not control Parliament, and if Parliament confers on a Minister a power to make regulations how can the court inquire into those regulations beyond ascertaining whether they are within the power?"35 This brief statement exemplifies how both the justification and the limits of judicial review could be explained in terms of Parliamentary sovereignty.

\section{IV}

It is this socio-political transformation that sets the background for the emergence, in fits and starts, of the doctrines we now call 'administrative law'. This background is worth mentioning within an account of the development of English private law, because it shows how these new doctrines addressed the problem of controlling a growing executive branch within a theoretical framework that addressed concerns about courts' political legitimacy in doing so. I will argue that we can find similar concerns in the development of English private law. That development itself is a bit of a surprise. With administrative law doctrines (such as ultra vires) having grown out of more traditional common law principles, ${ }^{36}$ the divide between public law and private law was considered useful for organizational and pedagogical purposes, but it was not taken to reflect a substantive divide in the law. ${ }^{37}$ What is distinctive about the emergence of English private law is the claims made by academic lawyers working in property, tort, contract, restitution (and perhaps also trusts) that together these branches of law constituted a distinct and substantively different division of the law. Private law was not just a collective name to gather otherwise diverse areas of law; there was, rather, a certain idea of private law that unified these areas of law and gave them distinct meaning and content. Departures from what was described as 'the law's true essence' in these areas, failure to understand what private law or any its

${ }^{34}$ Dicey, n. 26, p. $15^{1}$. Whether ultra vires still explains the theoretical foundation of judicial review, a question that has been the subject of considerable debate, is not a question I will address here.

${ }^{35}$ [1947] K.B. 736,739 (CA).

${ }^{36}$ D. Oliver, 'What, If Any, Public-Private Divide Exists in English Law?' in M. Ruffert (ed.), The Public-Private Law Divide: Potential for Transformation (2009) 1, 3-5.

${ }^{37}$ English academics in the early twentieth century saw the distinction as merely a matter of 'convenience'. See Allison, n. 1, pp. 8-1 1, 124. Even much more recently this view still has its defenders. See C. Harlow, "Public" and "Private" Law: Definition without Distinction' (1980) 43 Modern Law Rev. 241; Oliver, n. 36, p. 16 ("we have, at most, some separate substantive and adjectival public laws, but we do not have a coherent divide between public and private law or laws.'). 
branches 'genuinely' were, inevitably 'distorted', 'debased' and 'manipulated' the law. ${ }^{38}$

I do not claim that those who made these claims did not believe them; but I do believe that the unity they claimed for private law was the outcome of their effort to understand the law in a particular way, and hence was more manufactured than natural: it was not an inherent feature of private law, but the conclusions of their efforts to mould private law in a particular way. And just as the rise of public law could be explained as a response to a changing socio-political environment, so was the impetus for doing so in private law. My first step in challenging the conceptual story about private law will be to show that the reason for the new demarcation between public and private law has been a concern with the political legitimacy of courts having almost exclusive control over the development of the law in this area. I therefore argue that the emergence of private law as a distinct category of English law at the particular time that it did, is better explained not by lawyers' sudden realization of the true nature of (English) law (a nature that somehow eluded English lawyers of past centuries) but by the changing political environment at a particular time in history.

As already mentioned, the combination of the doctrine of Parliamentary sovereignty and the modern regulatory state has resulted in the familiar division of labour between Parliament and courts, and the boundary line between what I called public law and administrative law was developed to match those limits. The problem with private law was that it seemed to flout this divide, as here was a large area of law about which it was difficult to say that the courts were not involved in making law. Against a background in which substantive rules were now considered properly to belong to the legislature, there was a need to justify leaving much of the law-making power in this area of law in the hands of the courts and explain how this was consistent with the supremacy of Parliament. I will call this 'the Political Legitimacy Problem'.

At its most abstract, a solution to this problem had to show that the common law was not political. In a post-legal realist, post-CLS world, this was a difficult claim to defend, ${ }^{39}$ and $I$ will argue that separating private law from public law was an important element in this endeavour. One of the distinctive marks of private law in the eyes of the Private Lawyers was its separateness from politics, both from within-

38 The quoted words come from M. McInnes, 'Resisting Temptations to "Justice", in R. Chambers et al. (eds.), The Philosophical Foundations of the Law of Unjust Enrichment (2009) 1 oo, 101, 127, and N.J. McBride, 'Rights and the Basis of Tort Law', in D. Nolan \& A. Robertson (eds.), Rights in Private Law (2011) 331, 332, 361. Additional examples of this attitude are found in text accompanying notes $40-41$ below.

${ }^{39}$ As acknowledged in P. Birks 'Equity in the Modern Law: An Exercise in Taxonomy' (1996) 26 U. of Western Australia Law Rev. 1, 4, 98 ('The [legal] realists and post-realists ... have a strong hand'). In the United States, due to a different political tradition and a stronger influence of legal realism, the solution was quite different. Cf. D. Priel, 'Is There One Right Answer to the Question of the Nature of Law?', in W. Waluchow \& S. Sciaraffa (eds.), The Philosophical Foundations of the Nature of Law (2012) 322. 
the nature of private law or of its branches was the product of conceptual analysis, not political theory-but also from without. If much public law came to reflect shifting political ideology, to stay private and distinct, private law had to be insulated from 'distorting' influences coming from public law. In what follows I identify four strategies for addressing the Political Legitimacy Problem. Though there is some overlap between these ideas, for analytical purposes I consider them below separately.

(a) Judges don't make law. To make sense of this idea in the context of the common law required resorting to the old notion according to which court decisions were not themselves the law, but merely a reflection or evidence of the law. This view may sound outdated, but consider the claim made recently by Nicholas McBride that there is 'absence of any understanding among the judges as to what tort law is for'. ${ }^{40}$ Tort law is thus presented not as a product of the work of the courts, but as some idea that exists prior to and outside of the courts, such that if the courts fail to identify it, that in no way shapes tort law, but rather shows that the courts have made a mistake. In a similar fashion Andrew Burrows has recently attacked the Australian High Court and to a lesser degree the House of Lords for failing follow the real law of restitution. ${ }^{41}$ Despite allegedly claiming to merely organize and present the law as it is found in courts decisions, Burrows's position presupposes that the true law of restitution is for the courts to discover and follow, not to create. At times the view that judges do not make law is defended even more explicitly. Birks chastised the House of Lords decision that departed from an earlier decision for claiming to have changed the law. This, said Birks, is the proper domain of the legislature. He said this in spite of the 1966 practice statement, and the fact that the doctrine the House was departing from was itself the creation of the court. ${ }^{42}$

On this view, the true principles of private law somehow pre-exist their judicial enunciation, and therefore identifying them does not violate democratic principles. Nonetheless, I think that of all strategies of defending the distinctness of private law, this has been the least popular, perhaps because virtually all the senior British judiciary have expressed the view that they do make law. ${ }^{43}$

(b) The separation between law-as-will and law-as-reason. This approach is in some respects a variant of the previous one, or perhaps an attempt to explain it, but it also contains something else, namely a more explicit recounting of two competing theories of authority. According to one, which we may call the Hobbesian view, it is

\footnotetext{
${ }^{40}$ N.J. McBride \& R. Bagshaw, Tort Law (2012, 4th ed.) xviii.

${ }^{41}$ See A. Burrows, 'The Australian Law of Restitution: Has the High Court Lost Its Way?' in E. Bant \& M. Harding (eds.), Exploring Private Law (2010) 67, 70-71, 85 .

${ }^{42}$ See P. Birks, 'Mistakes of Law' (2000) 53 Current Legal Problems 205, 21 7-1 8.

${ }^{43}$ For a few examples see Lord Reid, 'The Judge as Law Maker' (1972) 12 J. of the Society of Public Teachers of Law 22; K. Diplock, The Courts as Legislators (1965); Lord Devlin, 'Judges as Lawmakers' (1964) 72 Listener 261; T. Bingham, 'The Judge as Lawmaker: An English Perspective' in The Business of Judging: Selected Essays and Speeches 1985-1999 (2000) 25; cf. Lord Radcliffe, Law and Its Compass (1960) 39.
} 
not Wisdom, but Authority that makes a Law'. ${ }^{44}$ To the extent that the common law is law, it is because it is accepted by an act of will of a political authority. The alternative view, which we may call the Cokean view, is that it is the reason of the law, and more precisely, the artificial reason of the law that gives it its authority. The latter view need not deny that judges in some sense make law, but it insists that they make law in a particular way, one that is different from the way legislatures make law, and for this reason is less open to the Political Legitimacy Problem. Judge-made law is not law in virtue of an act of will, but in virtue of its rational force. ${ }^{45}$ If Hobbes's Dialogue has the student of the common law argue that law is all reason and Hobbes's alter ego respond that all law is an act of will, the divide could be revitalized in modern times by splitting the difference: public law (much of it legislatively-created, thus reflecting the shifting political aims of different governments) is put on the side of will, private law is placed on the side of reason.

One easily finds statements from Private Lawyers that convey this idea. The 'common law is based on reason" ${ }^{46}$ we are told by Private Lawyers, and as 'Reason legitimates' and 'Reason communicates' ${ }^{47}$ it provides an independent source of legitimacy to private law, regardless of its popular appeal. A slightly different example comes from Burrows's statement that 'for the common law to react according to the political fad of the moment would be to contradict its very essence' ${ }^{48}$ Such a view, that seeks to exclude democracy from the common law (and that is what is being excluded, even if it is disparagingly described as 'the political fad of the moment') is supported by the view that unlike the principles that ground law, which can be fairly easily determined and objectively validated, in the domain of politics (of will) there are only subjective preferences. ${ }^{49}$

The distinction between will and reason is related to another distinction, mentioned earlier, between law as concerned with the protection of rights and law as concerned with the promotion of welfare. To its proponents, the former is an area of law that can begin from relatively uncontroversial premises and derive detailed conclusions through conceptual analysis and deductive logic, while the latter is the domain in which law serves to formally institutionalize competing political views on

${ }^{44}$ T. Hobbes, 'A Dialogue between a Philosopher and a Student, of the Common Laws of England', in A. Cromartie \& Q. Skinner (eds.), Writings on Common Law and Hereditary Right (2005) 10. Here and elsewhere Hobbes makes it clear that he is talking not just of statute law, but 'generally of Law', and that his target is Edward Coke.

${ }^{45}$ See M.J. Detmold, 'Law as Practical Reason' (1989) 48 Cambridge Law J. 436.

${ }^{46}$ N.J. McBride \& P. McGrath, 'The Nature of Restitution' (1995) 15 Oxford J. of Legal Studies 33, 33.

${ }^{47}$ P. Birks, 'Three Kinds of Objection to Discretionary Remedialism' (2000) 29 U. of Western Australia Law Rev. 1, 16.

48 A. Burrows, Understanding the Law of Obligations (1999) 122; also A. Beever, Rediscovering the Law of Negligence (2007) 8.

49 A. Burrows, The Law of Restitution (2011, 3rd ed.) 4; R. Stevens, Torts and Rights (2007) 309 ('our rights should not be decided, or altered, according to a judge's personal assessment of the balance of a basket of policy concerns'). 
which (so the thought might be) there can be no rational argument. ${ }^{50}$ Especially among defenders of the view that tort law is concerned with the protection of rights, one finds support for the view that what rights we have is a matter that can be determined fairly uncontroversially. ${ }^{51}$

(c) Private law depends on pre-political (moral) common sense. A different solution to the Problem of Political Legitimacy is asserting that private law finds its foundations in common sense morality. Thus, Robert Stevens tells us that it is unnecessary to be a profound thinker'52 to understand and justify tort law, and for this reason the subject is 'much more boring than is commonly supposed' ${ }^{53}$ This view can be traced back to the idea, expressed among others by Blackstone, that the common law is nothing but shared custom, that its authority 'rests entirely upon general reception and usage', and that its content is proven by 'shewing that it hath been always the custom to observe it'. ${ }^{54}$ Thus, the content of tort law can be 'deduced from the nature and experience of ourselves, and the world and society in which we live in'. ${ }^{55}$ This solution presupposes that common sense is roughly the same for all, so that virtually everyone will reach the same answer on these questions. For this reason we can take deciding on these matters from democratic majorities without worrying about violating Parliamentary supremacy.

(d) Private law is a matter of legal expertise. An altogether different response tries to solve the Political Problem by arguing that private law is the product of disinterested, and politically neutral, expertise. Birks, the most vigorous defender of this position, has clearly seen this view as very different from the common sense view just considered. He warned that 'the community's sense of justice is prone to pathological lapses'. ${ }^{56}$ Nor, in his view, is appeal to moral intuition any better. ${ }^{57}$ For him, the true mark of the rule of law is legal expertise shielded, as much as possible,

50 Cf. Blackburn, Low E Co. v. Vigors (1886) 17 Q.B.D. 553, 558: 'every general proposition laid down by judges, as a principle of law, as distinguished from an enactment by statute, is the statement of some ethical principle of rights and wrong applied to circumstances arising in real life' (emphasis added).

${ }^{51}$ Stevens, n. 49, p. 330. For a critique see D. Priel, 'That Can't Be Rights' (2011) 2 Jurisprudence 227 .

${ }^{52}$ Stevens, n. 49 , p. 329 .

${ }^{53} \mathrm{Id}$., 307 .

${ }^{54}$ See W. Blackstone, Commentaries on the Laws of England, i. *68. I offer here one reading of Blackstone, which I find convincing, but acknowledge that there are other, more 'rationalistic' interpretations of his work. On this see further in D. Priel, Book Review, (2007) $57 \mathrm{~J}$. of Legal Education 579, 588-89. This disagreement bears little on the point I make in the text as the argument has its modern defenders, eg, A. Kramer, 'Proximity as Principles: Directness, Community Norms and the Tort of Negligence' (2003) 11 Tort Law Rev. 70, 73 (the wrongdoing that tort law protects 'is defined by social norms').

${ }^{55}$ Stevens, n. 49 , p. 330.

${ }^{56}$ Birks, n. $47,16$.

${ }^{57}$ See $i d$. ('The judge as expert in applying the law is entitled to respect. The judge as a fountain of intuitive justice is not'); Birks, n. 39, p. 23 ('Justice is impeded and endangered by unrestrained intuition'). 
from such influences. In what he called a 'democratic bargain[,] ... some part of [the demos'] power shall be ceded to unrepresentative experts whose expertise consists in the interpretation of the law'; in return, the experts' side of the bargain is that 'they will not usurp the functions of the representative legislature' ${ }^{58}$ To achieve that, the legal experts must be 'doing something different from the legislator and something that cannot be done by just any commuter on the Clapham bus' ${ }^{59}$ If the former is the domain of political will and the latter the place of unconstrained intuition, the lawyers' answer must be based on 'hard-won mastery of ... specialised rationality'. ${ }^{60}$

Birks clearly echoes here Coke's artificial reason of the law ${ }^{61}$ not Blackstone's vision of the common law as reflecting custom. Here, law-or more precisely private law-can maintain its separateness from politics and thus overcome the Political Legitimacy Problem by being turned into an almost technocratic enterprise. 'But for the need to retain a trace of normativity' Birks said when discussing unjust enrichment, 'one might just as well speak of pink enrichment' ${ }^{62}$ The task of the jurist is to develop an elaborate taxonomic 'map' of the law, one in which all possible events are classified. Subsequently, all that would remain is to place any given event in its correct category, its right place on the map. Not just the task of application but even the map-making itself had to be a matter of technical expertise: it should be done by 'look[ing] downwards to the cases', not by appealing to some 'unknowable justice in the sky'. ${ }^{63}$

$\mathbf{V}$

None of the ideas considered in the last section is entirely new; but they were all refocused by the Private Lawyers to the domain of private law. In this way they have sought to establish a clear divide between private law and public law for the sake of justifying leaving the central law-making power in this area of law to the judges. These, if you wish, were the Private Lawyers' responses to an English version of a countermajoritarian difficulty.

Ideas, however, are not enough. In addition to these theoretical responses, the Private Lawyers have considered various institutional mechanisms meant to guard the common law from politicization and in this way keep private law apart. I consider six of them below.

${ }^{58} I d ., 98-99$.

${ }^{59}$ Id., 99; Beever, n. 48, p. 173; cf. Peter Birks, 'Adjudication and Interpretation in the Common Law: A Century of Change', (1994) 14 Legal Studies 156, 174-75 ('It is the law, with less and less help from other social structures, which must assure the most diverse groups of the security and value of their essential interests').

${ }^{60}$ Birks, n. 57, p. 99.

${ }^{61}$ Prohibitions del Roy (1607) 77 E.R. 1342, 1343.

${ }^{62}$ P. Birks, Unjust Enrichment (2005, 2nd ed.) 275.

${ }^{63}$ P. Birks, An Introduction to the Law of Restitution (1989, rev. ed.) 23, 19. 
(a) The depoliticization of judicial appointments. Judicial appointments in the early twentieth century were highly politicized. Legal acumen or respect in legal circles did not count for much in senior judicial positions; the right political connections and views did. And then, rather swiftly, procedures changed. ${ }^{64}$ The new settlement coincided with a turn towards the professionalization of the judiciary and the retrenchment of the idea that judicial appointments and promotion should be based on legal acumen, not party affiliation. Today Private Lawyers draw an explicit link between their conception of private law and a non-politically appointed judiciary ${ }^{65}$

(b) The separation of the common law and legislation. English courts have adopted various doctrines to limit the potential influence of statute on the development of the common law. The best known is that statutes in derogation of the common law should be strictly interpreted. More interesting are the reactions of judges to the suggestion that the courts should develop common law doctrines by analogy from legislation. The Court of Appeal has responded to this idea stating that it has 'nothing to commend it but its audacity' ${ }^{66}$ Plainly, this is not the only possible approach, ${ }^{67}$ but the distrust of the products of the legislature ${ }^{68}$ compared with the unbridled faith in the powers of the courts, ${ }^{69}$ cannot be separated from some of the more theoretical claims considered in the previous section. They sit particularly well with the theoretical suggestions made in the last section that the common law reflects reason whereas legislation is 'short-term party politics' ${ }^{70}$

(c) Self-imposed limits on the scope of judicial innovation. English common law judges used to be innovators. With little forewarning and not much fanfare they invented

${ }^{64}$ See A.A. Paterson, 'Judges: A Political Élite?' (1974) 1 Brit. J. of Law and Society 118 , $120-26$.

${ }^{65}$ See Stevens, n. 49, pp. 31 2-13; Birks, n. 47, p. 17.

${ }_{66}$ Malone v. Metropolitan Police Commissioner [1980] Q.B. 49, 63. The origins of attitude are centuries old. See J. Beatson, 'Has the Common Law a Future?' (1997) 56 Cambridge Law J. 291, 299; Roscoe Pound, 'The Common Law and Legislation' (19o8) 21 Harvard Law Rev. $383,385-86$.

${ }^{67}$ Compare the approach in civil law jurisdictions where analogizing from legislation is standard practice. Id., 388-89; R.S. Summers \& M. Taruffo, 'Interpretation and Comparative Analysis' in D.N. MacCormick \& R.S. Summers (eds.), Interpreting Statutes: A Comparative Study (1991) 461,471 .

${ }^{68}$ Contrast J.M. Landis, 'Statutes and the Sources of Law' (1965 [first published 1934]) 2 Harvard J. on Legislation 7, 25 ('Experts legislative draftsmen are commonly attached to legislatures.... If it be true that law reflects and should reflect experience rather than logic, legislation born of such an urge demands careful and sympathetic consideration.') with Lord Radcliffe, 'Law and the Democratic State' (1956) $5^{2}$ Brief 1, 7 (expressing concern that the political system, especially when governed by two parties, will result in 'a system of law ... [that] bears an [sic] [un]recognisable relation to those ideas of equity and wisdom which most men would wish to see imprinted on the fabric of society').

${ }^{69}$ See Burrows, n. 48 , p. 136 ('I have too much faith in the judiciary, and too much love of the deductive technique of common law development to wish to see the law frozen by widespread legislative intervention'). One is tempted to reply, with Mark Twain, that 'faith is believing what you know ain't so'.

${ }^{70}$ Burrows, n. 48 , p. 122 . Dicey, n. 10, pp. 397-98 expresses a similar view. 
new torts such as the tort of inducing breach of contract, intentional infliction of mental injury, and a tort protecting against losses from substances escaping from neighbouring property. Somewhere in the middle of the twentieth century, with a few exceptions, English judges became much less willing to innovate in this way. ${ }^{71}$ Viscount Simonds reflected the new mood:

For to me heterodoxy, or, as some might say, heresy, is not the more attractive because it is dignified by the name of reform. Nor will I easily be led by an undiscerning zeal for some abstract kind of justice to ignore our first duty, which is to administer justice according to law, the law which is established for us by Act of Parliament or the binding authority of precedent. The law is developed by the application of old principles to new circumstances. Therein lies its genius. Its reform by the abrogation of those principles is the task not of the courts of law but of Parliament. ${ }^{72}$

This attitude is definitely still with us. Think of the endless judicial procrastination over whether there is a tort of infringement of privacy. A more specific, astounding, recent example is the decision in Jain v. Trent Strategic Health Authority. ${ }^{73}$ Despite having no legal constraint limiting them from reshaping an earlier law which was exclusively created by the courts, a unanimous House of Lords reached a decision that all members of the panel considered unjust. The only way to make sense of that decision is that Law Lords felt that changing or adjusting a judicially-created doctrine to reach what they believed was a better outcome, would undermine their legitimacy more than handing down an unjust decision.

(d) Deciding cases on principle, not policy. Private Lawyers have argued that courts should not rely on policy considerations in private law, with one of them going so far as describing doing so 'an admission of failure'. ${ }^{74}$ The failure in question is the failure to show how purely legal considerations can answer the question of individuals' rights and duties towards each other (as well as individuals rights and duties towards the state).

(It is worth noting parenthetically that though Private Lawyers may seem to follow the courts' reluctance to addressing political questions in cases of negligence liability involving public authorities, the two approaches are quite different. The Private Lawyers adopt here something like Ronald Dworkin's distinction regarding the kind of considerations courts should rely on. Courts sometimes follow a different idea, one that has some links to the work of Fuller, ${ }^{75}$ which is concerned with the kind of disputes courts should consider. Disputes that are deemed predominantly 'political' (perhaps because polycentric) are also considered inappropriate for

${ }^{71}$ For a similar assessment see R. Stevens, The English Judges: Their Role in the Changing Constitution (2005, rev. ed.) 31-33, 42-43.

${ }^{72}$ Scruttons Ltd. v. Midland Silicones Ltd. [1962] A.C. 446, 467-68; see also Magor and St Mellons Rural District Councilv. Newport Corp [1952] A.C. 189, 191.

73 [2009] UKHL 4, [2009] 1 A.C. 853.

${ }^{74}$ A. Beever 'Policy in Private Law: An Admission of Failure' (2006) 25 U. of Queensland Law J. 287; also Stevens, n. 49, p. 3o8; E.J. Weinrib, Corrective Justice (2012) 69-72; C. Witting, 'Duty of Care: An Analytical Approach' (2005) 25 Oxford J. of Legal Studies 33, 39-42.

${ }^{75}$ See L.L. Fuller, 'The Forms and Limits of Adjudication' (1978) 92 Harvard Law Rev. 353 . 
judicial decision. Whatever are the merits of this latter view, it does not entail the complete exclusion of policy.)

(e) The separation of public and private duties. Historically, there was no clear distinction between public and private duties (and correspondingly between public and private rights).$^{76}$ From the 1970 os courts and commentators have begun distinguishing between private and public duties: for a public body to have a public law duty does not imply that failing to comply with it can give rise for a claim for compensation. This can be so only if the public duty is also a private law duty. Whatever one thinks of this distinction it has one practical effect, and that is to keep private law and public law apart. While complete separation here is difficult to maintain, the prevailing view among Private Lawyers has been that it is a mistake to infer a private right (on in other words, a tort law action) from a violation of a public duty. ${ }^{77}$ On this interpretation public bodies' public duties do not give rise and do not in any way shape the private law duties of public bodies, so that their private duties are identical to those of individuals. That, however, is not the only possible interpretation of their relationship. A different interpretation, favoured by Lord Atkin, was that the public duties of public authorities give shape to their private law duties. $^{78}$

(f) Academic emphasis on doctrinal scholarship and education in private law. prominent Private Lawyers like Peter Birks have played a leading role in the effort to maintain private law scholarship and education as heavily focused on doctrinal analysis. In this way they sought to prevent the infiltration into private law of ideas from theoretical approaches that often challenged the divide between public and private law. Indeed, whereas in public law there was growing influence from political theory, political science, and other areas that have highlighted the political nature of public law, the emphasis on doctrinal scholarship in the areas of contract, tort, restitution, and property law (while ignoring non-doctrinal work on these areas of law), has served to maintain the goal of keeping private law away from the touch of legislatures. Notice that insisting on doctrinal scholarship requires an extra step from the claim that courts should limit themselves to traditional legal materials and to narrow considerations pertaining only to the parties before them. One may well favour an approach in which scholars take broad normative considerations into

${ }^{76}$ See Ashby v. White, (1703) 2 Ld. Raym. 938 (Q.B.), and especially Chief Justice Holt's dissent that influenced the vote in the House of Lords (reported in $3 \mathrm{Ld}$. Raym. 320) and which was followed by later courts. Central to Holt's dissent was the idea that a violation of a right (whatever its source) gives rise to remedy. See 2 Lt. Raym. at 953. It was the laterrejected majority opinions at Queen's Bench that emphasized the distinction between public and private right. Id., 942, 949 .

77 The distinction, says Allison, n. 1, pp. 26-27, 179, appeared 'with little authority and without mentioning the traditional English rejection' of it. For recent judicial support see Lord Hoffmann in Stovin v. Wise [2004] UKHL 15, [2004] 1 W.L.R. 1057, at [23]. Additional support for this view by Private Lawyers are cited in D. Priel, 'Torts, Rights, and Right-Wing Ideology' (2011) 19 Torts Law J. 1, 17-19.

78 East Suffolk Rivers Catchment Board v. Kent [1941] A.C. 74, 88-91 (Lord Atkin, dissenting). 
account for the sake of creating the kind of rules that will then relieve the courts of the need to engage in such questions. But in reality such a separation between academic and judicial work is hard to maintain. By insisting on the primacy of doctrinal scholarship, by engaging in it, one can maintain the idea that a nonpolitical private law is possible, and therefore that the courts can be kept in charge of it. In this way, doctrinal scholarship served, among other things, as a response to the Problem of Political Legitimacy.

\section{VI}

There are several ironies in this story. One is that defenders of English private law, who often insist on the theoretical difference between English private law and the private law of civilian countries, ${ }^{79}$ end up with a view of law that bears unmistakable similarity to civil law models and is quite different from traditional common law. With their insistence on a clear distinction between private and public law, and of the former as a domain of pure law unadulterated by policy, with their emphasis on (seemingly) politically-neutral conceptual analysis, the Private Lawyers end up close to late nineteenth century German Begriffsjurisprudenz (jurisprudence of concepts) ${ }^{80}$ Closer to our subject, a surprising conclusion from the previous discussion is that contemporary Private Lawyers can see themselves as the true heirs of Dicey. That may seem counterintuitive at first: Dicey insisted that in English law there was no distinction between private and public law, while they argue the exact opposite. One way of understanding my argument is that after Dicey's battle against public law has been lost, Private Lawyers have sought to maintain an enclave of the Diceyean conception of law within one corner of a legal system that's increasingly different from Dicey's image of English law. ${ }^{81}$

Consider the three components of Dicey's account of the rule of law: the presentation of discretion (as manifested in administrative bodies) as contrary to law; the equality in the law applicable to everyone including, especially, the law applied to public bodies; and the suggestion that foundational principles of English constitutional law are derived from court decisions deciding cases rather than from general declarations in constitutional documents.

\footnotetext{
${ }^{79}$ See Stevens, n. 49, pp. 342-47; Nicholas J McBride, 'Duties of Care-Do They Really Exist?' (2004) 24 Oxford J. of Legal Studies 417, 439-40.

${ }^{80}$ See M. Reimann, 'Nineteenth Century German Legal Science' (1990) 31 Boston College Law Rev. 837, 857 ('[Savigny] focused almost exclusively on private law ... while he excluded constitutional, administrative and other public law as a concern of politics, not legal science'); $c f$. Dicey, n. 16, p. 23, where Dicey criticizes what is 'miscalled international law', which he thought is better called 'the rules of public ethics'.

${ }^{81}$ They did so by echoing what has been described as Dicey's signal achievement, the association of Englishness with the common law and with values of 'social detachment and personal autonomy'. See J. Stapleton, 'Dicey and His Legacy' (1995) 16 History of Political Thought 234, 255-56; S. Collini, Public Moralists: Political Thought and Intellectual Life in Britain, I $850-1930(1991) 287$.
} 
All three are preserved, and forcefully defended, by contemporary Private Lawyers. The idea that discretion is opposed to the rule of law is clearly stated by Birks who said that '[Judges'] authority is legitimated by their expertise. A rational rule of law has to have its experts. Community justice does not. Discretionary remedialism takes one long step away from the rationality of the rule of law and towards direct access to the community's sense of justice'. ${ }^{82}$ The view that private law is committed to a form of equality because it treats everyone in the same way, has been repeatedly stated by Private Lawyers. ${ }^{83}$ At a lower level of abstraction, much of the domain of negligence liability of public authorities as analysed by Private Lawyers is subsumed under the general category of omissions, because, we are told, the law in this area 'applies just as much to public bodies as it does to private persons' ${ }^{84}$ Lord Hoffmann, probably the most sympathetic and prominent proponent of Private Lawyers' ideas among the English judiciary in recent years, has similarly expressed the view that in this area of law public authorities were (and should be) 'treated in exactly the same way as if it had been a private citizen'. ${ }^{85}$

Finally, just as the Diceyean English constitution is inferred from judicial decisions determining the rights of private individuals and not from general declaratory documents, Private Lawyers have expressed the view that the rights and duties that they believe are at the core of private law are properly derived from individual cases. For instance, Stevens tells us that tort law 'is concerned with the vindication of our rights'. He went on to say that 'abolishing the law of torts altogether ... would mean the abolition of most of our legal rights' ${ }^{86}$ On this view our (primary) legal rights are necessarily constituted by tort law as developed by the courts dealing with cases, and it is impossible for them to be created elsewhere-why else would the abolition of tort law in favour of, say, a social compensation scheme entail the abolition of our legal right to bodily integrity? Another manifestation of this attitude is found in Private Lawyers' vehement opposition to the codification of private law. Burrows called binding codes 'dangerous', without any evidence that codification both in and outside the common law world has had any negative effect

${ }^{82}$ Birks, n. 47 , p. 18 ; also Burrows, n. 48 , p. 62.

${ }^{83}$ See e.g., E.J. Weinrib, The Idea of Private Law (1995) 76-8o; E.J. Weinrib, 'The Special Morality of Tort Law' (1989) 34 McGill Law J. 403, 409.

${ }^{84}$ McBride \& Bagshaw, n. 40, p. 208.

${ }^{85}$ Lord Hoffmann, 'Reforming the Law of Public Authorities Negligence', available at http:/ / www.barcouncil.org.uk/media/100362/lord_hoffmann_s_transcript_171109.pdf, p. 3. In his appearance before the Law Commission Stevens is reported to have expressed the same view. See Law Commission, Administrative Redress: Public Bodies and the Citizen (no. 322, 2010) 33.14 .

${ }^{86}$ Stevens, n. 49 , p. 325 . 
on the development of law in those jurisdictions. ${ }^{87}$ Even Birks, an otherwise unwavering admirer of civilian ways, was unsympathetic to codification. ${ }^{88}$

By itself, the similarity between the Private Lawyers' conception of private law and Dicey's understanding of law (in general) could be considered of limited historical interest. Indeed, my claims about the origins of private law thinking in English law are consistent with the view that private law is, as Private Lawyers insist, politically neutral. ${ }^{89}$ Now comes what I suspect will be a more controversial part of my overall argument: we have seen that Dicey's ideas were based on his economic liberalism. I will now argue that these similarities show that despite Private Lawyers' efforts to present private law as politically neutral, their conception of private law is afflicted by similar political commitments. ${ }^{90}$

Though both parts of my overall argument are about the 'political' nature of the Private Lawyers' arguments, they are different. The part of the argument developed in previous sections was political in the sense that it argued that the emergence of private law has been a response to the Political Legitimacy Problem that arose in a certain time and place. Here I argue that Private Lawyers' work has been political in something closer to the everyday sense of the word. These two arguments seem to be in conflict with each other. In earlier sections I maintained that the separation of private from public law was made for the sake of keeping law apart from politics; I now suggest that in doing so Private Lawyers were adopting certain political positions. Can the two claims be reconciled? I think they can, but it requires attributing an error to the Private Lawyers. I think their error consists of believing that their responses to the Problem of Political Legitimacy let them escape the political fray, whereas in reality, their responses put them, consciously or not, right in the middle of it. Such an error is most likely to happen when a certain political ideology is presented as neutral, as common sense, or in our context, as merely reflecting the values inherent in the common law.

We have already seen how Private Lawyers' choices were defended as reflecting common sense or apolitical expertise. Here I show how some of their implications are politically contentious. Full treatment of this claim requires much more space than I have here, but I can offer a couple of examples of the way Private Lawyers have sought to shape the content of private law in a way that is not politically neutral

${ }^{87}$ Burrows, n. 48, p. 136 . For a similar attitude see Stevens, n. 49, pp. 300, 35o. Contrast this with the more informed view in R. Goode, Commercial Law in the Next Millennium (1998) 26.

${ }^{88}$ P.B.H. Birks, 'More Logic and Less Experience: The Difference between Scots Law and English Law', in D.L. Carey Miller \& R. Zimmermann (eds), The Civilian Tradition and Scots Law (1997) 167, 189 ('The common law will be killed by an English Civil Code'); Birks, n. 39 , p. 99 .

${ }^{89}$ See P. Birks, Book Review, (2003) 119 Law Q. Rev. 156, 159 ; R. Stevens, 'Torts', in L. Blom-Cooper et al., The Judicial House of Lords ${ }_{1} 876-2009$ (2010) 629, 651-52; Beever, n. 48, pp. $5^{2-55}$.

90 Cf. D. Sugarman, 'The Legal Boundaries of Liberty: Dicey, Liberalism, and Legal Science' (1983) 46 Modern Law Rev. 102, 111. 
but rather gives it the appearance of conceptual necessity so as to blunt potential criticism of its political nature. ${ }^{91}$

My first example, one that I will discuss only briefly, deals with the claim that the fundamental equality of the common law means that tort law must treat individuals and public authorities in the same way. This view, which as we have seen, has a clear forerunner in Dicey's work, has resulted in a restrictive attitude towards liability of public authorities, at least in comparison with some other jurisdictions. This view is presented as a neutral position in that it treats all negligence defendants in the same way, but this is an essentially libertarian position, which, as John Rawls put it, '[o]ne noteworthy feature of [which] is that the state is just like any other private association'. ${ }^{92}$ Given that individuals who find themselves in certain relations to each other often have duties to act and protect others, the suggestion that the state has no duties towards individuals and that whatever it does towards them is merely a 'conferral of a benefit', can only mean that public authorities stand in a relation of complete strangers to the public. Whatever benefits the state provides is thus treated as a form of charity, despite the fact, among other things, that the funding of public authorities comes from the public. This is to treat the fundamental change in the relation between individual and state that took place in the course of the twentieth century (whether one likes it or not) as though it never happened. That is not a politically neutral position..$^{93}$

A more general point touches on what Dicey called 'the individualism of the common law'. ${ }^{94}$ Dicey made it a point to tout the common law's continued commitment to individualism as a shield against what he saw as the deleterious effects of collectivism on self-reliance, and against legislative regulation for its 'gradual and indirect' detrimental impact on safety. ${ }^{95}$ Contemporary Private Lawyers are perhaps less explicit but remarkably similar. They talk about the 'rugged individualism' of the common law and the 'premium' it places 'upon our freedom to choose how we live our lives' ${ }^{96}$ Now, 'individualism' means different things and there

${ }^{91}$ For more on the political underpinnings in the work of some contemporary Private Lawyers see Priel, n. 77.

${ }^{92}$ J. Rawls, Political Liberalism (2005, expanded ed.) 264.

${ }_{93}$ Of course, even on its own terms the supposedly 'equal' treatment of private and public bodies may be an illusion. McBride and Bagshaw state that courts will not find a duty of care when they fear that the imposition of a duty might lead 'a public official not to do his job properly' for fear of being sued. McBride \& Baghsaw, n. 4o, p. 114. They admit that in other contexts the courts have not found such arguments convincing and admit it is very difficult to say why' this is so. Id., 115 . One striking difference is that all the cases they mention in which courts found this argument compelling involved public authorities (judges, military commanders, police, health and safety inspectors, social services, and local councils). All the cases they mention in which it failed involve private bodies (doctors, referees, barristers, expert witnesses).

${ }^{94}$ Dicey, n. 10, p. lxxi.

${ }^{95} I d$., $257-58$.

${ }_{96}$ R. Bagshaw, 'The Duties of Care of Emergency Service Providers' [1999] Lloyd's Maritime and Commercial Law Q. 71, 7 1; Stevens, n. 49, p. 9. 
is no problem with accepting the idea that the common law typically involves particular individuals' claims against other particular individuals. But the alleged individualism of the common law becomes much less neutral when we are told that there is conceptual inconsistency between private law and the pursuit of 'social justice', that any attempt of doing so is not a bad strategy or even bad morals, but that it 'manipulate[s]' and 'abuse[s]' the law. ${ }^{97}$ Likewise, the individualism of the common law is no longer politically neutral when we are told by Lord Hoffmann that 'the individualist philosophy of the common law' implies that '[p] eople of full age and sound understanding must look after themselves and take responsibility for their actions' ${ }^{98}$ It is here that the political affinity between Dicey and the Private Lawyers becomes apparent: Just as Dicey thought that there was some incongruity between English law and 'collectivism', we are now told that we should not 'twist and distort' tort law in pursuit of 'collective goals'. ${ }^{99}$ In other words, 'individualism' here is shorthand for a particular, by no means uncontroversial, moral and political position. ${ }^{100}$

To say that the common law is individualistic in this sense can mean one of two things. One possibility is that there is something inherently individualistic about the common law, that it cannot be anything but individualistic in this sense; the other is that the common law is not necessarily individualistic, but that in actual practice it is. For the Private Lawyers' arguments to work the individualism must be somehow necessarily inherent to the common law. It is only then that relying on its underlying values might not fall foul of the Political Legitimacy Problem. (Even then, one might argue that if the common law is necessarily politically biased, then it should be abolished.) As it happens, however, this view is implausible. To see why, consider another case in which Lord Hoffmann has spoken about the individualism of the common law. In deciding whether tort liability should be imposed on a public authority, he said, courts must decide upon the potential 'cost, not only in money but also in deprivation of liberty' from limiting risks people are exposed to. This 'balance between risk on the one hand and individual autonomy on the other', he added, 'is not a matter of expert opinion. It is a judgment which the courts must make and which in England reflects the individualist values of the common law.' ${ }^{101}$

${ }_{97}$ McInnes, n. 38, pp. 101, 115 (the scare quotes around 'social justice' are in the original).

${ }^{98}$ Reeves v. Commissioner of Police of the Metropolis [2000] 1 A.C. $360,3^{68 .}$

${ }_{99}$ See McBride, n. 38, p. 361. By contrast, McBride has supported tort law being 'distort[ed]' for the sake of protection of rights. See McBride, n. 79, p. 430. If tort law can be 'distorted' for promoting one vision of tort law, why not for the sake of another?

${ }^{100}$ It is the sentiment found in Samuel Smiles, Self-Help (186o, new ed.) 5, where Smiles spoke of 'this strong individualism which makes and keeps the Englishman really free, and brings out fully the action of the social body'.

${ }^{101}$ Tomlinson v. Congleton Borough Council [2003] UKHL 47, [2004] A.C. 46, at [47]. That this is not the only possible way of thinking about the common law can be seen from the Court of Appeal decision, [2003] 2 W.L.R. 1120, as well as from the views, on and off the bench, of Lord Bingham. See in particular 'The Uses of Tort Law' (2010) 1 J. of European Tort 
For the courts to develop the law on the basis of these values they must be somehow non-political, and this is possible if the values are seen to be somehow already embedded in the common law. To follow them then would be almost like following a precedent. Only in this way can we reconcile the recognition that underlying the common law is a particular political ideology with the claim that private law is a matter of legal expertise: the judges use their knowledge of the vast content of the law to identify the values embedded in it.

Unfortunately, this suggestion is difficult to accept. First, that these values are somehow embedded in the common law does not make them less political and less in need of political justification. Private Lawyers themselves believe that 'individualism' is true of the common law, but not of civilian private law. ${ }^{102}$ This shows that English private law could have been different; and this means the claim that the common law is individualistic is nothing more than a statement about the political views of the people (judges, barristers, legal scholars) who have played the most central role in developing its doctrines. Second, the different voices and possibilities have not just existed outside the common law world. Competing voices and interpretations of the values underlying the common law have always existed. The cases and commentators thought 'correct' by the Private Lawyers are not so in virtue of mere expertise, but rather reflect a normative choice to highlight certain views of certain people at the expense of others.

If this is true, then the analogy I drew between Dicey's conception of law and the Private Lawyers' conception of private law is complete: both have defended a particular conception of law as reflecting the true nature of English law, when in fact both views are derived, at least in part, from a certain political ideology. The conclusion to draw from this is that by the Private Lawyers' own lights, on the basis of the arguments they themselves have made, the Diceyean ideology that is at the heart of their understanding of contemporary private law renders their project political, and as such, potentially illegitimate.

Let me draw out one little-noticed but significant implication of this. The only remotely plausible response to the claims made here is that individualism has become so much part of the common law that it is no longer open for judges to change it. They must follow its implications and if whatever ideological change is sought, it must come from the legislature. I have my doubts about this view (a view does not become less political because of the passing of time), but even granting it, it implies that the Private Lawyers can have no claim against calls for changing the common law through legislation by those who wish to better protect values not currently embedded in the common law. Moreover, claiming to be mere legal experts, they can have nothing to say on whether such changes should be introduced. And yet the Private Lawyers have been equally vociferous in their opposition to calls for legislative reforms such as the adoption of a New Zealand-style alternative to tort law, of no-fault liability to traffic accidents, or the expansion of the

Law 3, and his dissent in Van Colle v. Chief Constable of the Hertfordshire Police [2008] UKHL 50, [2009] 1 A.C. 225 .

${ }^{102}$ See the sources cited in note 79 . 
negligence liability of public authorities. ${ }^{103}$ In this way the Private Lawyers have completely sealed private law from reform they disapprove of: on the one hand, we must accept individualism as somehow inherent in the nature of the common law; on the other, we are told that legislative changes to the common law are undesirable, because they politicize it. When presented in this way, the Private Lawyers' preference for the common law over legislation appears, just like Dicey's similar preference, motivated by the belief that judges more than the legislature will stand up for the values they favour.

Let me summarize the argument presented in this section from a slightly different angle. There are two ways in which people have been defending private law. One type of argument has been clearly political, coming from libertarians or classical liberals who have contended that a greater share of our lives should be regulated by private law. ${ }^{104}$ By contrast, there is the allegedly non-political work of scholars who have defended private law on the basis of seemingly conceptual and taxonomical arguments. If the argument in this essay is successful, the difference between these two groups is, in fact, smaller than it seems.

\section{VII}

This essay has advanced two related but independent arguments. The first, descriptive or interpretive, was concerned to explain the emergence of private law as a distinct category of English law in the latter part of the twentieth century. I have argued that contrary to the explanations offered by the Private Lawyers themselves, the explanation for the pressure to distinguish private law from public law has been political, and in particular the need to justify leaving the development of these areas of law in the hands of the courts. That this approach had a political motivation, however, does not yet show that it was committed to a particular political position. My second argument went a step further and argued just that by showing the similarity in the arguments offered by Dicey in support of his conception of law and those of contemporary Private Lawyers.

One may accept the first argument and reject the second. Even if one accepts only the first one, it reveals an important point that I hope should underlie future discussions on private law: the divide between private law and public law is not part of nature, or even the nature of law. But if one also accepts the second argument, does that show that private law is illegitimate? Not necessarily. Private Lawyers' own position rests on two premises, one that acknowledges the potential problem of legitimacy in leaving private law in the hands the courts and a second that contends that their understanding of this area of law provides an adequate response to the

${ }^{103}$ See Law Commission, n. 85, $\$ 2.9$ (reporting that Stevens and Hoffmann 'disagreed vigorously' with suggestions for legislative reform).

${ }^{104}$ F.A. Hayek, The Mirage of Social Justice (1977) 31 (talking about a 'private law society' as what 'makes an Open Society possible'); R.A. Epstein, Simple Rules for a Complex World (1995). At a slightly further remove see R. Nozick, Anarchy, State and Utopia (1974) ch. 7. The clearest exponent of this view in the history of English law is probably Baron Bramwell. 
challenge. My argument challenged the second premise, and it did so on the basis of the Private Lawyers' own work. That does not yet show that there are no other responses to the challenge of legitimacy. What it does show, however, is the need to justify private law on the basis of moral and political premises. Such work would have to offer substantive arguments for the superiority of a certain view of private law and institutional arguments addressing concerns about the political legitimacy of unelected judges continuing to be given the central role in developing certain areas of law. It may be (although, admittedly, I do not think so) that there is a good argument of this sort to justify something not very different from the Private Lawyers' conception of private law. The impossible dream is the belief that one could somehow answer (or avoid) these questions exclusively by analysing concepts and past cases. 